\title{
Purine Nucleotides Metabolism and Signaling in Huntington's Disease: Search for a Target for Novel Therapies
}

\author{
Marta Tomczyk $^{1, * \mathbb{D}}$, Talita Glaser ${ }^{2}$, Ewa M. Slominska ${ }^{1} \mathbb{D}$, Henning Ulrich ${ }^{2} \mathbb{D}$ and Ryszard T. Smolenski ${ }^{1, *}$ \\ 1 Department of Biochemistry, Medical University of Gdansk, 80-210 Gdansk, Poland; eslom@gumed.edu.pl \\ 2 Department of Biochemistry, Institute of Chemistry, University of São Paulo, São Paulo 05508-000, Brazil; \\ talita.glaser@usp.br (T.G.); henning@iq.usp.br (H.U.) \\ * Correspondence: marta.tomczyk@gumed.edu.pl (M.T.); rt.smolenski@gumed.edu.pl (R.T.S.)
}

Citation: Tomczyk, M.; Glaser, T.; Slominska, E.M.; Ulrich, H.; Smolenski, R.T. Purine Nucleotides Metabolism and Signaling in Huntington's Disease: Search for a Target for Novel Therapies. Int. J. Mol Sci. 2021, 22, 6545. https://doi.org/ $10.3390 /$ ijms 22126545

Academic Editor: Ivano Condò

Received: 31 May 2021

Accepted: 14 June 2021

Published: 18 June 2021

Publisher's Note: MDPI stays neutral with regard to jurisdictional claims in published maps and institutional affiliations.

Copyright: (C) 2021 by the authors. Licensee MDPI, Basel, Switzerland. This article is an open access article distributed under the terms and conditions of the Creative Commons Attribution (CC BY) license (https:/ / creativecommons.org/licenses/by/ $4.0 /)$.

\begin{abstract}
Huntington's disease (HD) is a multi-system disorder that is caused by expanded CAG repeats within the exon- 1 of the huntingtin (HTT) gene that translate to the polyglutamine stretch in the HTT protein. HTT interacts with the proteins involved in gene transcription, endocytosis, and metabolism. HTT may also directly or indirectly affect purine metabolism and signaling. We aimed to review existing data and discuss the modulation of the purinergic system as a new therapeutic target in HD. Impaired intracellular nucleotide metabolism in the HD affected system (CNS, skeletal muscle and heart) may lead to extracellular accumulation of purine metabolites, its unusual catabolism, and modulation of purinergic signaling. The mechanisms of observed changes might be different in affected systems. Based on collected findings, compounds leading to purine and ATP pool reconstruction as well as purinergic receptor activity modulators, i.e., P2X7 receptor antagonists, may be applied for HD treatment.
\end{abstract}

Keywords: purine metabolism; purinergic signaling; Huntington's disease

\section{Introduction \\ 1.1. Huntington's Disease Pathophysiology}

Huntington's disease (HD) is a rare neurodegenerative disease that extensively affects the central nervous system. The disorder is inherited in an autosomal dominant manner. Clinically, HD is manifested by the occurrence of cognitive, mental, and motor disorders [1]. One of the earliest signs of the motor disorder in Huntington's disease is chorea, i.e., involuntary dance-like movements. Patients with HD are also characterized by bradykinesia (motor slowness) and dystonia (the occurrence of unnaturally slow, prolonged muscle spasms that cause repetitive torsional movements affecting various parts of the body) [2]. Thus, the motor disorders in Huntington's disease visibly affect the attitude, balance, and gait of HD patients. Furthermore, with the development of the disease, the speech of a patient with HD becomes unclear. Moreover, swallowing difficulties may also occur, which may lead to weight loss [3]. In addition to movement disorders, HD causes prominent changes in personality and mood. Most often HD patients suffer from depression, apathy, anxiety, irritability, outbursts of anger, impulsiveness, obsessive-compulsive syndromes, sleep disorders, and withdrawal from social life [4]. A characteristic feature of Huntington's disease is also cognitive impairment, which affects the understanding, reasoning, and memory. It includes slower thinking, problems with concentration, organization, planning, decision-making, answering questions, short-term memory disorders, as well as limited problem-solving skills and understanding of new information [2]. The incidence of HD in Europe is estimated at 5 to 10 cases per 100,000 people. In adults, the first symptoms appear between 30 and 50 years of age, after which the disease relentlessly progresses over the next 15-20 years.

The genetic cause of HD is the occurrence of multiple repeats of the CAG nucleotide sequence within the huntingtin gene (HTT) localized on chromosome 4 , which results in the 
elongation of the polyglutamine stretch in the HTT protein. The number of CAG nucleotide sequence repeats in the healthy population varies from 6 to 35 , while the presence of over 36 repeats defines the pathogenic HD allele. In cases with 36 to 39 CAG repeats within the HTT gene, the symptoms of the disease may be reduced or completely unnoticeable [1]. Moreover, the expansion length of CAG repeats correlates with the onset of the disease [5]. Huntingtin (HTT) is a multi-domain protein with a size of $348 \mathrm{kDa}$, with the highest level of HTT, demonstrated in the brain [6,7]. It has also been demonstrated outside the nervous system, in organs such as skeletal muscles or the heart [3]. The elongation of the polyglutamine stretch in exon 1 HTT leads to the formation of insoluble huntingtin aggregates, which are observed in both the early and advanced stages of the disease [8]. Aggregates of the mutated form of HTT (mHTT) have been identified in the brain as well as the outside central nervous system, e.g., in skeletal muscle [9]. In the CNS, mHTT mainly affects the basal ganglia region of the encephalon; this is the main region for voluntary and involuntary motor control, as well as cognition. This mutant protein sensitizes GABAergic neurons, making them vulnerable to NDMA induced excitotoxicity, leading to cell death. On the cellular level, HTT was found in the nucleus, endoplasmic reticulum, Golgi apparatus, and endosomes [10-12]. It has been shown that HTT interacts with proteins involved in gene transcription (e.g., CREB-binding transcription factor (CBP)), intracellular signaling (e.g., HIP14 protein), intracellular transport (e.g., HIP1 protein, HAP1), endocytosis, and metabolism (e.g., PACSIN1 phosphoprotein, vitamin D-binding receptor, hepatic X-receptor) [13,14]. Furthermore, HTT is essential during early embryogenesis and brain development. The inactivation of the HTT gene by targeting exon 1 or 5 is lethal in mice on embryonic day 7.5 (E7.5) of mouse development [15]. Biochemical and molecular pathways by which mutant huntingtin affects cellular dysfunction and death remain unclear; however, these might be caused not only by cellular mHTT accumulation but also the loss of HTT function leading to metabolic and signaling cascades impairment. Thus, in this work, we aimed to summarize the knowledge about the dysfunction of intra- and extracellular metabolism related to purines in the most affected by Huntington's disease systems (central nervous system, heart, skeletal muscle), its role in HD pathophysiology, and possible applications in HD treatment.

\subsection{Purine Nucleotides Metabolism and Signaling}

Purines play an important role as metabolic signals, controlling cellular growth and providing energy to the cell. In the central nervous system (CNS), the balance of nucleotides depends on a continuous supply of preformed purine and pyrimidine rings, mainly in the form of nucleosides. These nucleosides can enter the brain through the blood-brain barrier, or locally supplied by the conversion of extracellular phosphorylated forms (nucleotides) by extracellular nucleotidases located in the neuronal plasma membrane. The ectonucleotidases are divided into four families that differ in the specificity of the substrate and cellular location: nucleoside triphosphate diphosphohydrolases (NTPDases), nucleotide pyrophosphatase/ phosphodiesterases (NPPs), alkaline and acid phosphatases (ALP and $\mathrm{ACP}$, respectively), and ecto-5'-nucleotidase [16-19]. The NTPDase comprises NTPDase18; however, just NTPDase1, $-2,-3$, and -8 can efficiently hydrolyze all nucleotides. The NPP family includes seven members (NPP1-7) but as NTPDASE, only NPP1, NPP2, and NPP3 can hydrolyze nucleotides [17]. The ALP and ACP families comprise many ectoenzymes that dephosphorylate nucleotides (ATP, ADP, and AMP) and diverse substrates. The human $5^{\prime}$-nucleotides family has seven enzymes, although just one is anchored to the plasma membrane, known as CD73 [19,20]. Its main function is the production of extracellular adenosine. Later in the extracellular cascade, this adenosine can be converted to inosine through ecto-adenosine deaminase (eADA), and later to hypoxanthine by purine nucleoside phosphorylase (PNP) [21]. Then, after the transport of nucleosides and inosine/hypoxanthine into the cell, they are converted to AMP, ADP, and ATP by the basic cellular processes similar to those taking place in muscles. 
In skeletal muscles and the heart, high energy phosphate produced in oxidative phosphorylation is transported from mitochondria to the contractile apparatus via phosphocreatine $(\mathrm{PCr})$ shuttle. In the mitochondrial inter-membrane space, the energy of the high-energy phosphate bond of ATP can be transferred to creatine by mitochondrial creatine kinase (CK) resulting in the formation of PCr. In the cytosol, PCr can be used to resynthesize ATP from ADP by cytosolic CK. An important aspect of ATP involvement in energy metabolism is ATP degradation to adenosine- $5^{\prime}$-diphosphate (ADP) by ATPases (e.g., CK, sodium-potassium, or calcium myosin ATPase). There is also a possibility of further conversion of ADP to AMP that is mediated by adenylate kinase (AK). AMP is a substrate for two alternative pathways and enzymes: (1) $5^{\prime}$-nucleotidase (5NT) dephosphorylating AMP to adenosine that occurs in multiple isoforms, and (2) AMP deaminase (AMPD) converting AMP to inosine monophosphate (IMP). A unique aspect of purine nucleotide metabolism in the skeletal muscle is the function of the purine nucleotide cycle that besides AMPD, involves also adenylosuccinate synthetase, and adenylosuccinate lyase. This cycle plays an important role in energy balance through the maintenance of a high ATP/ADP ratio. Higher levels of intracellular AMP may also activate the AMPactivated protein kinase, an important protein involved in the regulation of cellular energy metabolism at both protein expression and activity levels. IMP is also the final product of purine de novo synthesis as well as purine salvage pathway (formation of IMP from hypoxanthine). The adenosine can be degraded to inosine by adenosine deaminase (ADA). Afterward, inosine can be converted to hypoxanthine by a purine nucleoside phosphorylase (PNP). Hypoxanthine can be converted by xanthine oxidoreductase activity to xanthine and uric acid. Nucleotide breakdown is highly organ and cell-type specific.

In the extracellular space, ATP can act as a signaling molecule by interacting with purinergic P2X and P2Y receptors. While ADP, UTP, UDP, and UDP-glucose interact with P2Y receptor subtypes, $\mathrm{P} 2 \mathrm{X}$ receptors are ligand-gated cation channels comprised of seven subtypes (P2X1-7) that assemble in a trimeric structure and upon stimulation allow cations inflow (such as $\mathrm{Na}^{+}, \mathrm{K}^{+}$, and $\mathrm{Ca}^{2+}$ ). P2Y receptors consist of eight subtypes (P2Y1, 2, 4, $6,11,12,13,14)$, in which $\mathrm{P} 2 \mathrm{Y} 1,2,4,6$ and 11 receptors couple to Gq proteins, activating phospholipase C (PLC)- $\beta$. Resulting in IP3 and diacylglycerol production, releasing $\mathrm{Ca}^{2+}$ from intracellular stores [22]. Instead, P2Y12,13, and 14 receptors couple to Gi proteins, inhibiting cAMP production [22]. While adenosine is a ligand for a category of receptors named P1. This category is composed of A1, A2A, A2B, and A3 subtypes. Within, A1 and $\mathrm{A} 3$ receptors are coupled to $\mathrm{Gi} / \mathrm{Go}$ proteins, inhibit adenylate cyclase and reduce cAMP levels upon activation; A2 receptors are coupled to Gs protein activating adenylate cyclase, increasing intracellular cAMP levels [23].

\section{Purines in Huntington's Disease}

\subsection{Cellular Changes Related to Affected Huntingtin Expression}

In 2014, Ismailoglu et al. investigated the metabolic profile of three syngeneic mouse embryonic stem cell (mESC) lines: HTT knock-out (KO), extended poly-Q (Htt-Q140/7), and wildtype mESCs (Htt-Q7/7). They found that HTT KO cells exhibited a 50\% decrease in ATP levels, concomitant with 2-fold increases in both ADP and AMP levels, which demonstrated that HTT protein activity is critical for the maintenance of high energy phosphates in the cell. Moreover, HTT KO exhibited unique expression of several molecules involved in purine synthesis, such as 5-aminoimidazole ribonucleotide (AIR), phosphor-ribosylformyl-glycineamidine (FGAM), formamidoimidazole-4-carboxamide ribotide (FAICAR), and 5'-phosphoribosyl-4-(N-succinocarboxamide)-5-aminoimidazole (SAICAR). It was accompanied by increased levels of the 5-aminoimidazole-4-carboxamide ribotide (AICAR) and the final pathway product of purine biosynthesis, IMP in those cells. Overall, it reveals a substantial acceleration of purine synthesis and turnover in HTT KO mESCs and suggesting the HTT importance in maintaining its mutual balance [24]. Following these findings, in 2020, we differentiated HTT KO mESCs to neurons as well as to cardiomyocytes and established that besides HTT absence, differentiation was successful [25,26]. It suggested 
that HTT is not a fundamental protein in cardiomyocyte development. The previous study in human pluripotent stem cells suggested that loss of HTT can reduce the induction of neural and neuronal genes during differentiation [27]. In the case of investigation purine metabolism, there were no changes in extracellular ATP concentration between HTT KO and WT neurons [25]. While HTT KO cardiomyocytes exhibited diminished intracellular ATP pool, which is in the line with data obtained from the MHTT overexpression cellular model $[26,28]$. HEK $293 \mathrm{~T}$ cell line transfected with plasmids expressing the mutant exon 1 of the HTT gene was characterized also by increased ADA activity, which suggested deteriorations in intracellular purine metabolism. Increased intracellular levels of metabolites such as inosine, hypoxanthine, and adenosine were found in HTT KO mESC [24]. Besides changes in intracellular purine metabolism, HD cells exhibited reduced activities of all extracellular enzymes, including eNTPD, e5NT, and eADA relative to the control [28]. In the case of purinergic signaling, the $\mathrm{Ca}^{2+}$ response of $\mathrm{P} 2$ receptors is impaired in mouse HTT $\mathrm{KO}$ neurons derived from mESC [25], while the $\mathrm{P} 2 \mathrm{Y} 2$ receptor response is only impaired in the presence of mHTT. Lack of P2Y2 receptor input induces the cells to upregulate their expression, as a feedback compensation effort [25].

\subsection{Purine Nucleotides Metabolism and Signaling in the Central Nervous System in Huntington's Disease}

One of the pathological hallmarks of the HD-affected brain is the gradual atrophy of the striatum (caudate nucleus and putamen) [29]. On gross examination, $80 \%$ of HD brains show atrophy of the frontal lobes. Thus, bilateral, symmetric atrophy of the striatum is observed in $95 \%$ of the HD brains [29]. The mean brain weight in HD patients is approximately $30 \%$ lower than in normal individuals. Striatal degeneration may lead to energy metabolism changes. It is clear that neurons are highly dependent on mitochondria ATP and $\mathrm{Ca}^{2+}$ buffering to maintain synaptic communication [30]. Moreover, neuronal mitochondria levels require to renew or adapt by efficient biogenesis and mitophagy during their lifespan [31]. There are undisputed data that highlighted the intensive deficits in energy metabolism in the human HD-affected brain. The striatum mitochondrial oxidative metabolism investigation underlined the selective defect of glycolysis in early and clinical symptoms in HD patients [31].

Interestingly, further analysis showed a significant correlation between impaired basal ganglia metabolism and functional capacity of HD patients [32]. Studies concentrated on lactate metabolism in HD-affected brains are ambiguous. Increased lactate levels were observed in the striatum of HD patients, which is discussed as inefficient oxidative phosphorylation leading to lactate accumulation from pyruvate via lactate dehydrogenase [32]. In contrast, reduced levels of lactate and citrate were shown in cerebrospinal fluid which may indicate impairment of glycolysis and TCA cycle function in HD subjects [32].

At the molecular level, brain energy metabolism deterioration included mitochondria dysfunction and trafficking interruption resulted in changes in the activities of molecules involved in energy balance [33]. In few independent studies of the striatum of mHTT knock-in mice, HD patients' postmortem brains, and lymphoblasts, the ATP/ADP ratio was reduced as a consequence of mHTT aggregation [34-36]. Significant reduction in mitochondrial spare respiratory capacity was reported in human HD fibroblasts and immortalized mHTT expressing mouse striatal cells when compared to wild-type cells indicating that mitochondrial bioenergetics is compromised by mHTT and supporting a toxic role of mHTT on mitochondrial bioenergetics [37].

Moreover, expression of full-length mHTT in immortalized striatal progenitor cells, derived from HD mice model $H d h \mathrm{Q} 111$, diminished the activity of mitochondrial respiratory chain complex II associated with intense sensitivity to $\mathrm{Ca}^{2+}$-induced decrease in oxygen consumption and mitochondrial membrane potential [33]. Mitochondrial $\mathrm{Ca}^{2+}$ transport is powered by the mitochondrial proton gradient, and increased neuronal $\mathrm{Ca}^{2+}$ modifies mitochondrial ATP production by uncoupling oxidative phosphorylation. In healthy conditions, $\mathrm{Ca}^{2+}$ can promote ATP synthesis by assisting pyruvate dehydrogenase, isocitrate dehydrogenase, $\alpha$-ketoglutarate dehydrogenase, and ATP synthase complex [31]. 
The reduced mitochondrial ATP levels and decreased ATP/ADP ratio found in mHTTcontaining striatal cells is linked to increased $\mathrm{Ca}^{2+}$ influx through N-methyl-D-aspartate (NMDA) receptors, and cell ATP / ADP ratio is normalized by blocking $\mathrm{Ca}^{2+}$ influx [36]. Mitochondria incubated with mHTT had increased sensitivity to $\mathrm{Ca}^{2+}$-induced opening of the MPT and release of cytochrome $\mathrm{c}$ and apoptosis induction [38], consistent with a direct effect of mHTT on mitochondrial $\mathrm{Ca}^{2+}$ handling [33]. As demonstrated by mitochondria isolated from lymphoblast cells of HD patients and HD mouse brain that have a reduced membrane potential and depolarize at lower $\mathrm{Ca}^{2+}$ concentrations than control mitochondria [39]. Both wild HTT and mHTT bind to the outer mitochondrial membrane in human neuroblastoma cells and cultured striatal cells [40]. It is established that full-length mHTT may impair mitochondrial motility in neurons through a toxic gain of loss of function from the polyglutamine tract [40]. Moreover, in vitro and in vivo models of HD are characterized by the altered mitochondrial trafficking that precedes neuronal dysfunction [41].

Roles of mitochondria in HD go far beyond ATP production and $\mathrm{Ca}^{2+}$ homeostasis; they can also regulate the metabolism of the reactive oxygen species (ROS) and apoptosis [42]. In addition, mHTT can affect the production of neurotrophins, such as brainderived neurotrophic factor (BDNF), impairing neuronal survival [43]. Noteworthy, BDNF promotes ATP synthesis and mitochondrial efficiency [44,45], which correlates with the fact that neurons are high-demand energy cells [46].

The reduction of mitochondrial bioenergetics in HD could be also a result of impairment of mitochondrial enzymes. Postmortem studies of the striatum of HD patients as well as cultured striatal neurons transfected with $\mathrm{N}$-terminus mHTT showed selective depletion of succinate dehydrogenase associated with decreased complex II enzymatic activity $[47,48]$. The mHTT can interfere with the TATA box binding protein (TBP)-associated factor 4 (TAF4)/ cyclic adenosine monophosphate (cAMP) response element-binding protein (CREB) signaling pathway [39]. Data are underlining a reduction in CREB phosphorylation and CRE signaling, which may contribute to the down-regulation of molecules involved in energy metabolism, such as peroxisome proliferator-activated receptor-gamma coactivator 1 alpha (PGC-1 $\alpha$ ) in mHTT expressing striatal cells [34]. Moreover, the reduction in PGC- $1 \alpha$ correlates with a diminished number of mitochondria in HD postmortem brain tissue [49,50]. The mHTT can impair the mitochondria biogenesis through PGC- $1 \alpha$ transcription inhibition as well. Post-mortem HD brain analysis shows lower levels of PGC- $1 \propto[38,51]$. In this way, cells increase the anaerobic metabolism in the basal ganglia of the HD patients, leading to improved lactate generation and its accumulation, thus promoting local inflammation [32].

AMP-activated protein kinase (AMPK), the main sensor for cellular energy content is also targeted by mHTT. It is activated by increased AMP/ATP ratios and induces PGC- $1 \alpha$ expression. AMPK is located in the nucleus in the HD striatum, downregulating the Bcl-2 family which leads to apoptosis [52,53].

As previously mentioned, brain capacity for de novo production of purines and pyrimidine rings is limited. In this regard, the brain demands constant provision of nucleosides produced in the liver and that cross the blood-brain barrier [30]. Adenosine and ATP in the extracellular milieu of the encephalon stimulate P1 and P2 receptors, respectively, acting as co-neurotransmitters. ATP and UTP can be released to the extracellular environment by microglia, astrocytes, and neurons themselves. They are also present in vesicles, where concentrations can be as high as $100 \mathrm{mM}$ (ATP) and $8 \mathrm{mM}$ (UTP) [30]. Thus, the imbalance of intra/extracellular nucleotides in neurons is related to various neurological disorders, such as Parkinson's, Alzheimer's, and Huntington's disease [54]. Figure 1 summarizes deteriorations in purine nucleotides metabolism and signaling in CNS affected by Huntington's disease.

$\mathrm{HD}$ is characterized by GABAergic loss due to excessive calcium response to glutamate stimuli. However, some evidence points to the impairment of some metabolic pathways link with purines metabolism [55]. Patassini and coworkers, using human postmortem brains, underwent metabolomics analyses of many brain areas typically affected in patients of Huntington's disease [56]. They found a decreased level of hypoxanthine but 
an increased level of inosine, indicating higher activity of ADA and low PNP. On the other hand, another study with a transgenic mouse model (R6/1) of HD highlighted an increased adenosine level in the cerebrospinal fluid in the middle stage of HD $[57,58]$. Furthermore, microarray analysis of the prefrontal cortex of HD patients showed a significant reduction in the transcript of CD73, suggesting that the synaptic adenosine level converted from AMP might be low. Moreover, the transcript levels of ENTs and AKs in HD patients are higher than in non-HD subjects [59]. Thus, it seems that regulation of the adenosine modulating enzymes in HD is still unclear and requires further investigation.

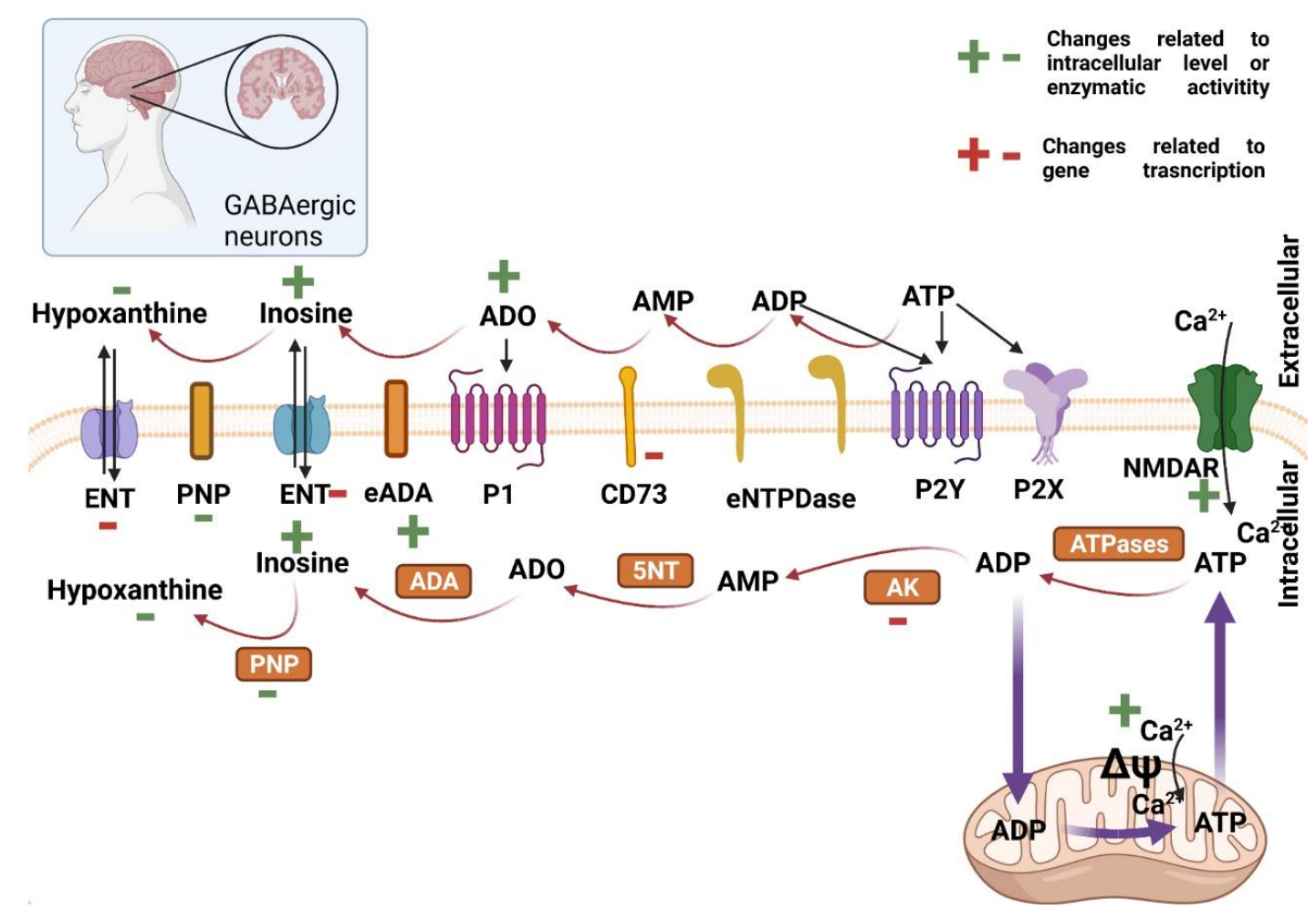

Figure 1. Purine metabolism and signaling in healthy and Huntington's disease striatal GABAergic neurons. In the neurons of the striatum, ATP is heavily produced by mitochondria which also play important role in buffering cytosolic calcium signaling. In the cytosol, many enzymes (orange boxes) can convert ATP to AMP, ADO, IMP, inosine, and hypoxanthine. The latter ones can be transported to the extracellular milieu by ENT. Extracellularly, ATP can also be converted to inosine and hypoxanthine through a similar cascade by extracellular-faced enzymes anchored to the cell membrane. CD73 is the only extracellular 5NT. Pathophysiology of Huntington's disease exerts alterations in the activity of enzymes (marked in green $+/-$ ) or by genomic expression (marked in red +/ -). In Huntington's disease condition, NMDA-glutamate receptors permit uncontrolled $\mathrm{Ca}^{2+}$ influx into cells. The excessive $\mathrm{Ca}^{2+}$ is transported to mitochondria, where it disrupts the membrane potential, releasing cytochrome $\mathrm{c}$ and promoting cell death. P1-Adenosine receptor; P2X - ATP receptor channel; P2Y-ATP/UTP receptor; ATPases_adenosine-5' -triphosphatases; AK-adenylate kinase; eNTPD—ecto-nucleoside triphosphate diphosphohydrolase; 5NT—5 nucleotidase; CD73—ecto- $5^{\prime}$ nucleotidase; eADA— ecto-adenosine deaminase; ADA—adenosine deaminase; PNP—purine nucleoside phosphorylase; ENT-ecto nucleoside transporter. Created with BioRender.com (accessed on 5 May 20021).

So far, few studies have investigated the role of purinergic signaling in Huntington's disease. Regarding the adenosine receptors, A1, which is expressed in neurons, microglia, astrocytes, and oligodendrocytes is impaired in Huntington's disease, this receptor usually protects against degeneration by inhibiting excitatory neurotransmission. A2A receptor is the most studied in HD; however, this is still controversial. Some studies detected downregulated A2A receptor expression in HD rodent models [60-64], while others improved the motor symptoms by antagonizing the A2A receptor $[65,66]$. Regarding ATP-sensitive receptors, the P2X7 receptor has been described as a major player, since its antagonism by 
Brilliant Blue G or selective P2X7 receptor inhibitors mitigates dyskinesia and body weight loss while preventing neuronal loss in the Tet/HD94 and R6/1 models [67].

Besides the P2X7 receptor, ATP and UTP-sensitive P2Y2 receptor plays important roles in HD. The intracellular signaling triggered by this receptor is impaired in neural precursor cells and neurons of HD human and mouse in vitro models. Moreover, the activity of the P2Y2 receptor favors the differentiation of neural stem cells towards a GABAergic neuronal fate [25]. Reestablishment of the activity of the P2Y2 receptor, promoting BDNF release, may prevent cell death.

\subsection{Purine Nucleotides Metabolism and Signaling in Skeletal Muscle and Heart in Huntington's Disease}

It has been shown that HD patients, except for the central nervous system disorders, are also characterized by a reduced (by about $50 \%$ ) muscular strength compared to healthy subjects [68]. Moreover, HD mice models were characterized by skeletal muscle atrophy [69]. It is also noted that R6/2 mice have altered the ultrastructure of transverse tubules in skeletal muscle fibers [70]. At the cellular level, aggregation of mHTT, the inclusion of poly-ubiquitinated proteins were found in myofibers and myonuclei in R6/2 mice $[9,71]$. The mHTT formation in skeletal muscle leads to defects, such as myofiber size reduction, type switching, and denervation [69,72-75]. In addition to changes in myofiber structure, transcriptional deregulation, and deteriorations in energy metabolism occur linked to impaired adenine nucleotide metabolism [76]. It has been noted that the skeletal muscles of HD patients are characterized by dysfunction of oxidative metabolism [77]. Studies in experimental mouse models have also shown that mitochondria isolated from the quadriceps muscle of the R6/2 mice model were characterized by reduced activity of the respiratory chain complexes [78]. Increased production of energy substrates such as lactate and acetate were also shown which confirms the presence of oxidative metabolism disorders [79]. Furthermore, in vitro myocyte cultures revealed disturbances of the mitochondrial membrane potential and cytochrome $\mathrm{c}$ release [80]. Moreover, increased levels of the mitochondrial pro-fission factor DRP1 and its phosphorylated active form, and decreased levels of the pro-fusion factor MFN2 in quadriceps of the R6/2 mice model were detected [78]. Interestingly, experimental studies have also shown a reduction in the level of PGC- $1 \alpha$, one of the proteins activated by peroxisomal proliferator gamma (PPAR $\gamma)$ in skeletal muscles of HD mice models as well as HD patients [50]. Additionally, the pharmacological activation of this co-activator led to increased expression of the skeletal muscle fiber proteins that suggested an important role of energy metabolism abnormalities in development of HD related myopathy [81]. Recently, Miller et al. report that the decrease of adenine nucleotides strictly linked with energy metabolism of the cell may lead to increased nucleotide degradation and contribute to the general pathophysiology of skeletal muscle atrophy in numerous disease states and conditions [82].

Besides skeletal muscle pathology, multiple epidemiological studies have shown that heart failure is the second cause of death in HD patients [83,84]. Reduced cortical and subcortical blood flow and heart rate have been reported as examples of pathological abnormalities in HD hearts [85-88]. HD patients' heart rate variability pattern is consistent with a higher sympathetic prevalence [89]. Further studies with HD animal models reaffirmed cardiac pathological events, such as variations in the heart rate and cardiac remodeling [90-92]. HD mouse models also revealed heart contractile dysfunctions, which might be a part of dilated cardiomyopathy. These changes were accompanied by an increased expression of fetal genes (the same is observed during the pathological remodeling of the heart) or the presence of interstitial fibrosis [90]. Interestingly, hearts of the HD mouse model R6/2 did not react to the same extent upon long-term treatment with isoproterenol (a compound that causes hypertrophy of the heart), as wild-type mouse hearts, suggesting the presence of signaling dysfunction that stimulates heart remodeling [93]. Hearts of HD mice models contained an increased number of apoptotic cells and degree of fibrosis [94]. Cardiomyocytes of the BACHD HD mouse model also showed electromechanical abnormalities, including prolonged action potential or arrhythmic contractions. Cellular arrhythmia was accompanied by increased activity of $\mathrm{Ca}^{2+} /$ calmodulin-dependent protein kinase II, suggesting 
disturbed calcium metabolism in the cell [95]. Dridi et al. show that intracellular calcium $\left(\mathrm{Ca}^{2+}\right)$ leaks via post-translationally modified ryanodine receptor/intracellular calcium release (RyR) channels may play an important role in HD pathology [96]. Furthermore, abnormalities of superoxide dismutase activity and glutathione peroxidase in the mitochondria of cardiomyocytes were observed. Cardiomyocytes from R6/2 mice also showed abnormalities in mitochondrial structure (loss of longitudinal shape and changes in mitochondrial density) that may lead to deteriorations in energy metabolism [97]. The studies performed on this model have also shown that the hearts of these mice are characterized by decreased activity of the mammalian target of rapamycin kinase complex 1 (mTORC1) that could be the cause of the reduced heart weight which is observed in this strain as well as the lack of resistance to severe and chronic stress [98]. Nevertheless, Kojer et al. highlighted no changes in mitochondrial oxidative chain complexes in R6/2 mice hearts [78]. Mechanistically, pathological huntingtin was found to be responsible for cellular death via inhibition of the proteasome in the cytosol and the nucleus of cardiomyocytes of R6/2 mice [97]. On the other hand, some studies indicated the mHTT absence may be the underlying mechanism, as observed in HD mouse hearts [78,90]. Taken together, cardiac dysfunction in HD might derive not only from autonomic nervous system dysfunction but also from several cellular and tissue defects, such as energy metabolism impairment, associated with dysfunctional cardiac purine metabolism and signaling [99]. Figures 2 and 3 illustrate changes in purine nucleotides metabolism and signaling in Huntington's disease-related myopathies.

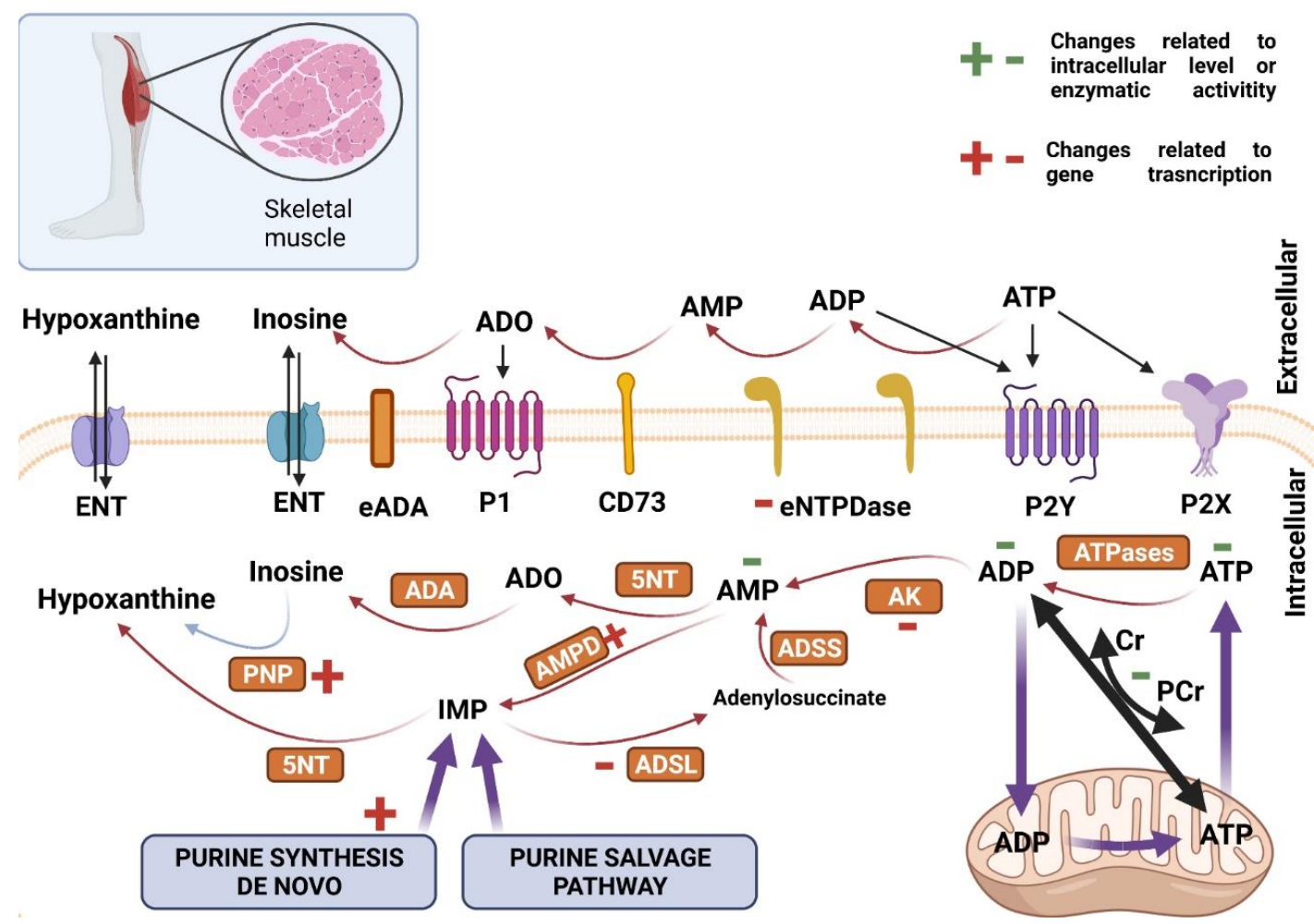

Figure 2. Purine metabolism and signaling in healthy and Huntington's disease skeletal muscles. In the skeletal muscles, ATP is heavily produced by mitochondria and transported to the cytosol through the phosphocreatine shuttle. In the cytosol, many enzymes (orange boxes) can convert ATP to AMP, ADO, IMP, inosine, and hypoxanthine. The later ones can be transported to the extracellular milieu by ENT. Extracellularly, ATP can be converted to inosine through a similar cascade by extracellular-faced enzymes anchored to the cell membrane. CD73 is the only extracellular 5NT. Pathophysiology of Huntington's disease exerts alterations in the activity of enzymes (marked in green $+/-$ ) or by genomic expression (marked in red +/-). P1-Adenosine receptor; P2X-ATP receptor channel; P2Y-ATP/UTP receptor; ATPases-adenosine5'-triphosphatases; AK—adenylate kinase; eNTPD—ecto-nucleoside triphosphate diphosphohydrolase; AMPD—AMP deaminase; 5NT—5' nucleotidase; CD73—ecto-5' nucleotidase; eADA—ecto-adenosine deaminase; ADA—adenosine deaminase; PNP — purine nucleoside phosphorylase; ADSL_adenylosuccinate lyase; ADSS—adenylosuccinate synthetase; ENT_ecto nucleoside transporter. Created with BioRender.com (accessed on 5 May 20021). 


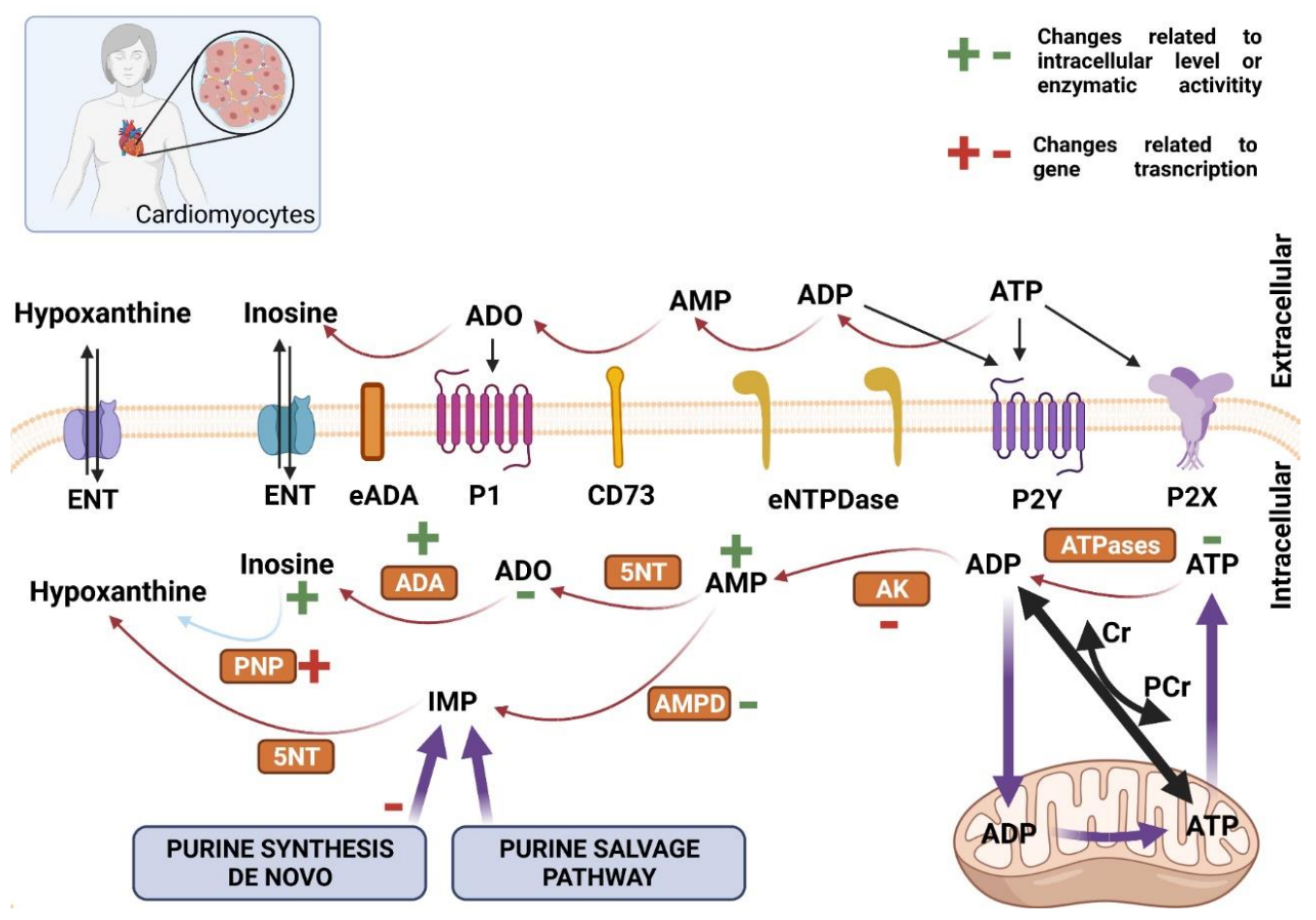

Figure 3. Purine metabolism and signaling in healthy and Huntington's disease cardiomyocytes. In cardiomyocytes, ATP is heavily produced by mitochondria and transported to the cytosol through the phosphocreatine shuttle. In the cytosol, many enzymes (orange boxes) can convert ATP to AMP, ADO, IMP, inosine, and hypoxanthine. The later ones can be transported to the extracellular milieu by ENT. Extracellularly, ATP can also be converted to inosine through a similar cascade by extracellular-faced enzymes anchored to the cell membrane. CD73 is the only extracellular 5NT. Pathophysiology of Huntington's disease exerts alterations in the activity of enzymes (marked in green +/ -) or by genomic expression (marked in red +/-). P1-Adenosine receptor; P2X-ATP receptor channel; P2Y-ATP/UTP receptor; ATPases-adenosine5'-triphosphatases; AK—adenylate kinase; eNTPD—ecto-nucleoside triphosphate diphosphohydrolase; AMPD—AMP deaminase; 5NT—5' nucleotidase; CD73—ecto-5' nucleotidase; eADA—ecto-adenosine deaminase; ADA—adenosine deaminase; PNP — purine nucleoside phosphorylase; ADSL_adenylosuccinate lyase; ADSS—adenylosuccinate synthetase; ENT_-ecto nucleoside transporter. Created with BioRender.com (accessed on 5 May 20021).

Research with HD patients detected reduced phosphocreatine to inorganic phosphate ratio in skeletal muscle of the symptomatic HD patients at rest (analyzed with a non-invasive 31P-MRS method). Moreover, muscle ATP/phosphocreatine and inorganic phosphate levels were significantly reduced in both symptomatic and presymptomatic HD subjects [100]. Furthermore, the maximum rate of mitochondrial ATP production during recovery from exercise was reduced by $44 \%$ in symptomatic HD patients and by $35 \%$ in presymptomatic HD carriers [77]. In the case of experimental models of HD, we have established that R6/2, as well as HdhQ150 HD mice, exhibited decreased ATP, ADP, and AMP concentrations in Extensor digitorum longus, Tibialis anterior, and Soleus. Moreover, a significant reduction of phosphocreatine ( $\mathrm{PCr}$ ) and creatine $(\mathrm{Cr})$ levels and the $\mathrm{PCr} / \mathrm{Cr}$ ratio was observed in the examined skeletal muscles [75]. Similar changes were observed in HD mouse model hearts. We observed decreased concentrations of ATP and phosphocreatine as well as diminished ATP/ADP ratios. Interestingly, in contrast to skeletal muscles, this was accompanied by increased AMP levels [101]. Elevated concentration of cardiac AMP may activate AMP-regulated protein kinase (AMPK), which was shown as an increased AMPK phosphorylation status and enhanced AMPK mRNA transcript (observed also in HD-affected skeletal muscle) [102].

The functionality of the ATP-phosphocreatine shuttle, the transcriptional signature of genes involved in purine metabolism in HD-affected skeletal muscle and hearts were also assessed [101,102]. In the case of genes involved in purine nucleotide catabolism, skeletal 
muscle mRNA levels of Adenylate kinase 1 exhibited significant down-regulation while the mRNA levels of ecto- $5^{\prime}$-nucleotidase remained unchanged in skeletal muscle (Extensor digitorum longus, Tibialis anterior, and Soleus). The same parameters were also studied in R6/2 mice hearts and demonstrated similar trends, such as reduced $A k 1$ (Adenylate kinase 1) and no changes in Nt5e transcript levels [101]. Nevertheless, cardiac e5NT activity was significantly reduced [103]. Similarly, cardiac Ampd3 (Adenosine monophosphate deaminase 3) transcript levels remained unchanged but AMPD activity was significantly reduced in R6/2 mice hearts, which could be caused by increased functional protein turnover or activity modulation in HD [101,103]. On the other hand, HD mouse skeletal muscle exhibited a significant upregulation of the Ampd3, which could be caused by its alteration by denervation which is exclusively linked to skeletal muscle atrophy [104]. Moreover, HD mouse model skeletal muscles and hearts exhibited significant expression down-regulation of two genes involved in the purine nucleotide cycle-adenylosuccinate lyase $(A d s l$,) and adenylosuccinate lyase 1. Expression profiles of selected genes involved in the intracellular adenosine metabolism such as $A d a$ (Adenosine deaminase) and $A d k$ (Adenosine kinase) were also measured. Significant up-regulation for the cardiac $A d a$ transcript (no changes in skeletal muscle $A d a$ transcript) and in the cardiac and skeletal muscle transcription levels of adenosine kinase were noted. This agrees with observed increased ADA activity, inosine concertation, and reduced adenosine levels in HD mouse model hearts [103]. Furthermore, mRNA levels of Pnp (Purine nucleoside phosphorylase) as well as PNP activity, which degrades inosine, remain unchanged in HD mouse hearts, while Pnp transcript levels were significantly and uniformly up-regulated in each examined HD mouse skeletal muscle. This observation suggests intensive inosine degradation to hypoxanthine and its release from the skeletal muscle cell. Extracellular hypoxanthine influx might activate its degradation by other cells to xanthine and then uric acid by xanthine oxidase or xanthine dehydrogenase. Moreover, inhibition of xanthine oxidase should protect against muscle mass loss, thus its activation may implicate opposite effects [105]. Interestingly, the skeletal muscle transcript of Xdh-(Xanthine dehydrogenase) was significantly up-regulated while in heart was unaltered, which confirms our earlier thesis. Furthermore, up-regulation of the mRNA levels of one of the enzymes involved in purine synthesis de novo, such as phosphoribosylglycinamide formyltransferase (Gart), was noted in HD skeletal muscle. A different observation was obtained in HdhQ150 mouse hearts, in whose Gart transcription was reduced. Nevertheless, cardiac and skeletal muscle transcript levels of other genes such as adenine phosphoribosyltransferase (Aprt) and amidophosphoribosyltransferase (Ppat) mRNA remained unchanged. Acceleration of purine de novo synthesis in HD skeletal muscle may indicate a greater demand for purine pool reconstruction in the cell. Probably, in HD mouse hearts, the signaling pathways aiming stabilized normal purine synthesis might be interrupted. Transcript rate analysis of genes involved in extracellular metabolism of purine nucleotides revealed significant down-regulation of Entpd2 (Ectonucleoside triphosphate diphosphohydrolase 2) in investigated HD-affected skeletal muscle and heart. Nevertheless, eNTPD activity analysis did not reveal any changes in its cardiac activity in R6/2 mice.

In the case of purinergic signaling, there are still no literature data available regarding its role in skeletal muscle and heart dysfunction related to HD. Nevertheless, it is well known that enhanced expression of specific purinergic system elements for example in dystrophic muscles are important for dystrophic pathophysiology and could increase its severity considerably [106]. Dystrophin mutations in Duchene muscular dystrophy (DMD) coincide with significant P2X7 upregulation in muscle and alter receptor signaling in mouse dystrophic myoblasts and myofibers. Thus, $\mathrm{P} 2 \mathrm{X} 7$ overexpression combined with the extracellular ATP-rich environment leads to cell dysfunction and death and ultimately to ineffective skeletal muscle regeneration [107]. Moreover, Ryten et al. demonstrated sequential expression of other purinergic receptors, such as P2X5, P2Y1, and P2X2 subtypes during the process of muscle regeneration [108]. Increased expression of the P2X1 receptor was reported in the aria of patients with dilated cardiomyopathy [109]. The protective role of P2X receptor activation (reduction of hypertrophy and increasing a life span) was highlighted in the calsequestrin overexpression model of cardiomyopathy $[110,111]$. 
Furthermore, roles for $\mathrm{P} 2 \mathrm{X} 7$ receptors in dilated cardiomyopathy have been reported similarly to skeletal muscle pathologies [112]. Based on this data, the role of purinergic signaling in HD affected skeletal muscle and heart might be a new and interesting topic to delve into.

\section{Purine Nucleotides Metabolism and Signaling as a Target for Huntington's Disease Therapies}

As presented in this review, there are many changes related to the purine metabolism in the central nervous system, skeletal muscle, and heart of HD patients, animals as well as cellular models. Nevertheless, these changes in those systems might involve different mechanisms. As described earlier, some studies indicated mHTT absence in HD mouse model hearts. Thus, the cardiac purine metabolism derangement could be caused only by HTT protein signaling dysfunction not by mutant protein accumulation, while in CNS and skeletal muscle purine metabolism impairment may be caused by loss of HTT protein function together with cellular mHTT accumulation. Deterioration in intracellular purine metabolism leads to the accumulation of purine metabolites that might be released from the cell via transporters. Indeed, we observed a significant accumulation of purine catabolites in HD mouse models and patients' serum, which was strongly correlated with HD progression [101]. Nucleosides, as well as nucleotides released from the cell, might be degraded in the extracellular purine metabolism and activate purinergic signaling pathways. In summary, purine metabolism and signaling impairment might affect the development and progression of energy metabolism, signaling, and hence function derangements in HDaffected systems. Therefore, therapies leading to their improvement may have promising clinical implications in HD treatment.

Based on collected findings, therapeutic strategies may include compounds that directly correct disrupted ATP levels and lead to adenine nucleotide pool reconstitution in HD. Compounds, such as the coenzyme $Q_{10}$ or creatinine, were widely tested and even investigated in clinical trials, but results were not promising [113]. An alternative might be the application of PPAR agonists, which have already undergone preclinical studies for the treatment of CNS, cardiovascular as well as skeletal muscle diseases. In 2016, the PPAR delta receptor agonist KD3010 was tested in the HD N171-82Q mouse model. Studies revealed improved motor function, reducing the progression of the neurodegenerative process and longer survival of treated animals [114]. Interestingly, studies performed by our team showed that simultaneous administration of adenosine metabolism inhibitors and substrates for adenine nucleotide synthesis improved mechanical functions of the heart, energy metabolism, and normalized adenine nucleotide pools $[115,116]$, pointing at possible applications in HD treatment.

AMPD makes part of another altered purine pathway in HD. Skeletal muscles of the HD mouse model showed enhanced AMPD activity, while its activity in the heart was reduced. Pharmacological inhibition, as well as AMPD expression deletion in mice, led to a substantial enhancement of skeletal muscle contraction, induced mainly by AMP accumulation [117]. Moreover, AMPD inhibition seems to be also protective in cardiovascular diseases $[118,119]$. AMPD activity reduction noted in HD mouse model heart led to increased cardiac AMP levels and AMPK activation, but due to increased ADA activity, it was not capable of preventing intracellular adenosine pool depletion. Thus, in HD affected hearts adenosine levels augment, with suggested cardioprotective properties [120]. Interestingly, adenosine has been used to treat also epileptic diseases and seizures that are commonly observed in the juvenile form of HD. Thus, adenosine might be also a target for HD-affected CNS [121,122].

Furthermore, drugs increasing not only the intracellular but also the extracellular adenosine levels in HD-affected brain and heart might be protective. As described earlier, the most important enzyme that controls extracellular adenosine metabolism balance is eADA. It is well known that extracellular adenosine pool depletion is an important factor in the development of cardiovascular pathologies. Recently, we highlighted the therapeutic perspectives of eADA inhibition in the treatment of cardiovascular diseases such as 
atherosclerosis, myocardial ischemia-reperfusion injury, or hypertension [123]. Moreover, a study underlined that intrastriatal administration of ecto-nucleoside transporter (ENT) inhibitors increased the extracellular level of adenosine in the striatum of R6/2 mice to a much higher level, compared to controls, and improved HD mouse survival [124].

Impaired purinergic signaling in HD in CNS concerns mainly P2X7 and P2Y2 receptors. P2X7 antagonism in HD prevents neuronal death [67]. Nevertheless, only the P2X7 receptor seems to be important in skeletal muscle as well as heart failure. It is known that antagonizing or knocking out $\mathrm{P} 2 \mathrm{X} 7$ or its downstream effectors, caspase- 1 or NLRP3, in animal models decreased infarct size, improved cardiac function, and enhanced survival post myocardial infraction via reduced interelukin $1 \beta$ and intereukin18 levels in the heart [125-128]. Furthermore, genetic ablation and pharmacological inhibition of the P2X7 axis alleviated dystrophic phenotypes in mouse models of dystrophinopathy and sarcoglycanopathy [107]. Therefore, its antagonism may be a more suitable approach to treat not only HD-affected CNS system but also skeletal muscle and heart.

Author Contributions: M.T. conceived the idea; M.T. and T.G. wrote the manuscript and prepared the graphs; E.M.S., H.U., and R.T.S. supervised the work. All authors have read and agreed to the published version of the manuscript.

Funding: This work was supported by the National Science Centre of Poland (grant number 2016/22/M/NZ4/00678). Furthermore, H.U. acknowledges funding for his research on Huntington's disease from the Sâo Paulo Research Foundation FAPESP (grant No. 2018/07366-4).

Institutional Review Board Statement: Not applicable.

Informed Consent Statement: Not applicable.

Data Availability Statement: No new data were created or analyzed in this study. Data sharing does not apply to this article.

Conflicts of Interest: The authors declare no conflict of interest.

\section{References}

1. Walker, F. Huntington's disease. Lancet 2007, 369, 218-228. [CrossRef]

2. Sturrock, A.; Leavitt, B.R. The Clinical and Genetic Features of Huntington Disease. J. Geriatr. Psychiatry Neurol. $2010,23,243-259$. [CrossRef]

3. McColgan, P.; Tabrizi, S.J. Huntington's disease: A clinical review. Eur. J. Neurol. 2018, 25, 24-34. [CrossRef]

4. Epping, E.A.; Paulsen, J.S. Depression in the early stages of Huntington disease. Neurodegener. Dis. Manag. 2011, 1, 407-414. [CrossRef]

5. Ross, C.A.; Tabrizi, S. Huntington's disease: From molecular pathogenesis to clinical treatment. Lancet Neurol. 2011, 10, 83-98. [CrossRef]

6. $\quad$ Li, S.H.; Schilling, G.; Young, W.S., 3rd; Li, X.J.; Margolis, R.L.; Stine, O.C.; Wagster, M.V.; Abbott, M.H.; Franz, M.L.; Ranen, N.G.; et al. Huntington's Disease Gene (IT15) Is Widely Expressed in Human and Rat Tissues. Neuron 1993, 11, 985-993. [CrossRef]

7. Li, S.-H.; Li, X.-J. Huntingtin-protein interactions and the pathogenesis of Huntington's disease. Trends Genet. 2004, 20, 146-154. [CrossRef] [PubMed]

8. Davies, S.W.; Turmaine, M.; Cozens, B.A.; DiFiglia, M.; Sharp, A.H.; Ross, C.A.; Scherzinger, E.; Wanker, E.E.; Mangiarini, L.; Bates, G. Formation of Neuronal Intranuclear Inclusions Underlies the Neurological Dysfunction in Mice Transgenic for the HD Mutation. Cell 1997, 90, 537-548. [CrossRef]

9. Moffitt, H.; McPhail, G.D.; Woodman, B.; Hobbs, C.; Bates, G.P. Formation of Polyglutamine Inclusions in a Wide Range of Non-CNS Tissues in the HdhQ150 Knock-In Mouse Model of Huntington's Disease. PLoS ONE 2009, 4, e8025. [CrossRef]

10. Hoffner, G.; Kahlem, P.; Djian, P. Perinuclear localization of huntingtin as a consequence of its binding to microtubules through an interaction with beta-tubulin: Relevance to Huntington's disease. J. Cell Sci. 2002, 115 Pt 5, 941-948. [CrossRef]

11. Godin, J.; Colombo, K.; Molina-Calavita, M.; Keryer, G.; Zala, D.; Charrin, B.C.; Dietrich, P.; Volvert, M.-L.; Guillemot, F.; Dragatsis, I.; et al. Huntingtin Is Required for Mitotic Spindle Orientation and Mammalian Neurogenesis. Neuron 2010, 67, 392-406. [CrossRef] [PubMed]

12. Veliera, J.; Kima, M.; Schwarza, C.; Kim, T.W.; Sappa, E.; Chaseb, K.; Aroninb, N.; Di Figliaa, M. Wild-Type and Mutant Huntingtins Function in Vesicle Trafficking in the Secretory and Endocytic Pathways. Exp. Neurol. 1998, 152, 34-40. [CrossRef] [PubMed]

13. Harjes, P.; Wanker, E.E. The hunt for huntingtin function: Interaction partners tell many different stories. Trends Biochem. Sci. 2003, 28, 425-433. [CrossRef] 
14. Schulte, J.; Littleton, J.T. The biological function of the Huntingtin protein and its relevance to Huntington's Disease pathology. Curr. Trends Neurol. 2011, 5, 65-78. [PubMed]

15. Duyao, M.P.; Auerbach, A.B.; Ryan, A.; Persichetti, F.; Barnes, G.T.; McNeil, S.M.; Ge, P.; Vonsattel, J.P.; Gusella, J.F.; Joyner, A.L.; et al. Inactivation of the mouse Huntington's disease gene homolog Hdh. Science 1995, 269, 407-410. [CrossRef] [PubMed]

16. Robson, S.C.; Sévigny, J.; Zimmermann, H. The E-NTPDase family of ectonucleotidases: Structure function relationships and pathophysiological significance. Purinergic Signal. 2006, 2, 409-430. [CrossRef] [PubMed]

17. Yegutkin, G.G. Enzymes involved in metabolism of extracellular nucleotides and nucleosides: Functional implications and measurement of activities. Crit. Rev. Biochem. Mol. Biol. 2014, 49, 473-497. [CrossRef]

18. Yegutkin, G.G. Nucleotide- and nucleoside-converting ectoenzymes: Important modulators of purinergic signalling cascade. Biochim. Biophys. Acta 2008, 1783, 673-694. [CrossRef]

19. Kukulski, F.; Lévesque, S.A.; Sévigny, J. Impact of Ectoenzymes on P2 and P1 Receptor Signaling. Adv. Pharmacol. 2011, 61, 263-299. [CrossRef]

20. Lin, J.H.-C.; Takano, T.; Arcuino, G.; Wang, X.; Hu, F.; Darzynkiewicz, Z.; Nunes, M.; Goldman, S.; Nedergaard, M. Purinergic signaling regulates neural progenitor cell expansion and neurogenesis. Dev. Biol. 2007, 302, 356-366. [CrossRef]

21. Shukla, V.; Zimmermann, H.; Wang, L.; Kettenmann, H.; Raab, S.; Hammer, K.; Sévigny, J.; Robson, S.C.; Braun, N. Functional expression of the ecto-ATPase NTPDase2 and of nucleotide receptors by neuronal progenitor cells in the adult murine hippocampus. J. Neurosci. Res. 2005, 80, 600-610. [CrossRef] [PubMed]

22. von Kügelgen, I. Pharmacology of P2Y receptors. Brain Res. Bull. 2019, 151, 12-24. [CrossRef] [PubMed]

23. Knight, G. Purinergic Receptors. In Encyclopedia of Neuroscience; Elsevier BV: Amsterdam, The Netherlands, 2009 ; pp. 1245-1252.

24. Ismailoglu, I.; Chen, Q.; Popowski, M.; Yang, L.; Gross, S.S.; Brivanlou, A.H. Huntingtin protein is essential for mitochondrial metabolism, bioenergetics and structure in murine embryonic stem cells. Dev. Biol. 2014, 391, 230-240. [CrossRef]

25. Glaser, T.; Shimojo, H.; Ribeiro, D.E.; Martins, P.P.L.; Beco, R.P.; Kosinski, M.; Sampaio, V.F.A.; Corrêa-Velloso, J.; OliveiraGiacomelli, Á.; Lameu, C.; et al. ATP and spontaneous calcium oscillations control neural stem cell fate determination in Huntington's disease: A novel approach for cell clock research. Mol. Psychiatry 2020, 1-18. [CrossRef] [PubMed]

26. Tomczyk, M.; Glaser, T.; Ulrich, H.; Slominska, E.M.; Smolenski, R.T. Huntingtin protein maintains balanced energetics in mouse cardiomyocytes. Nucleosides Nucleotides Nucleic Acids 2020, 1-8. [CrossRef] [PubMed]

27. Irmak, D.; Fatima, A.; Gutiérrez-Garcia, R.; Rinschen, M.M.; Wagle, P.; Altmüller, J.; Arrigoni, L.; Hummel, B.; Klein, C.; Frese, C.K.; et al. Mechanism suppressing H3K9 trimethylation in pluripotent stem cells and its demise by polyQ-expanded huntingtin mutations. Hum. Mol. Genet. 2018, 27, 4117-4134. [CrossRef]

28. Toczek, M.; Pierzynowska, K.; Kutryb-Zajac, B.-; Gaffke, L.; Slominska, E.M.; Wegrzyn, G.; Smolenski, R. Characterization of adenine nucleotide metabolism in the cellular model of Huntington's disease. Nucleosides Nucleotides Nucleic Acids 2018, 37, 630-638. [CrossRef] [PubMed]

29. Coppen, E.M.; Van Der Grond, J.; Roos, R.A.C. Atrophy of the putamen at time of clinical motor onset in Huntington's disease: A 6-year follow-up study. J. Clin. Mov. Disord. 2018, 5, 2. [CrossRef]

30. Ipata, P.L. Origin, utilization, and recycling of nucleosides in the central nervous system. Adv. Physiol. Educ. 2011, 35, 342-346. [CrossRef] [PubMed]

31. Jodeiri Farshbaf, M.; Ghaedi, K. Huntington's Disease and Mitochondria. Neurotox. Res. 2017, 32, 518-529. [CrossRef]

32. Herben-Dekker, M.; Van Oostrom, J.C.H.; Roos, R.A.C.; Jurgens, C.K.; Witjes-Ané, M.-N.W.; Kremer, H.P.H.; Leenders, K.L.; Spikman, J.M. Striatal metabolism and psychomotor speed as predictors of motor onset in Huntington's disease. J. Neurol. 2014, 261, 1387-1397. [CrossRef]

33. Intihar, T.A.; Martinez, E.A.; Gomez-Pastor, R. Mitochondrial Dysfunction in Huntington's Disease; Interplay Between HSF1, p53 and PGC-1 $\alpha$ Transcription Factors. Front. Cell. Neurosci. 2019, 13, 103. [CrossRef] [PubMed]

34. Gines, S.; Seong, I.S.; Fossale, E.; Ivanova, E.; Trettel, F.; Gusella, J.F.; Wheeler, V.C.; Persichetti, F.; MacDonald, M.E. Specific progressive cAMP reduction implicates energy deficit in presymptomatic Huntington's disease knock-in mice. Hum. Mol. Genet. 2003, 12, 497-508. [CrossRef] [PubMed]

35. Mochel, F.; Durant, B.; Meng, X.; O'Callaghan, J.; Yu, H.; Brouillet, E.; Wheeler, V.C.; Humbert, S.; Schiffmann, R.; Durr, A. Early Alterations of Brain Cellular Energy Homeostasis in Huntington Disease Models. J. Biol. Chem. 2012, 287, 1361-1370. [CrossRef] [PubMed]

36. Seong, I.S.; Ivanova, E.; Lee, J.-M.; Choo, Y.S.; Fossale, E.; Anderson, M.; Gusella, J.F.; Laramie, J.M.; Myers, R.H.; Lesort, M.; et al. HD CAG repeat implicates a dominant property of huntingtin in mitochondrial energy metabolism. Hum. Mol. Genet. 2005, 14, 2871-2880. [CrossRef] [PubMed]

37. Siddiqui, A.; Rivera-Sánchez, S.; Castro, M.D.R.; Acevedo-Torres, K.; Rane, A.; Torres-Ramos, C.A.; Nicholls, D.G.; Andersen, J.K.; Ayala-Torres, S. Mitochondrial DNA damage Is associated with reduced mitochondrial bioenergetics in Huntington's disease. Free. Radic. Biol. Med. 2012, 53, 1478-1488. [CrossRef] [PubMed]

38. Fuster-Matanzo, A.; Llorens-Martín, M.; De Barreda, E.G.; Avila, J.; Hernandez, F. Different Susceptibility to Neurodegeneration of Dorsal and Ventral Hippocampal Dentate Gyrus: A Study with Transgenic Mice Overexpressing GSK3 3 . PLoS ONE 2011, 6, e27262. [CrossRef]

39. Cui, L.; Jeong, H.; Borovecki, F.; Parkhurst, C.N.; Tanese, N.; Krainc, D. Transcriptional Repression of PGC-1 $\alpha$ by Mutant Huntingtin Leads to Mitochondrial Dysfunction and Neurodegeneration. Cell 2006, 127, 59-69. [CrossRef] 
40. Yablonska, S.; Ganesan, V.; Ferrando, L.M.; Kim, J.; Pyzel, A.; Baranova, O.V.; Khattar, N.K.; Larkin, T.M.; Baranov, S.V.; Chen, N.; et al. Mutant huntingtin disrupts mitochondrial proteostasis by interacting with TIM. Proc. Natl. Acad. Sci. USA 2019, 116, 16593-16602. [CrossRef]

41. Orr, A.L.; Li, S.; Wang, C.-E.; Li, H.; Wang, J.; Rong, J.; Xu, X.; Mastroberardino, P.G.; Greenamyre, J.T.; Li, X.-J. N-Terminal Mutant Huntingtin Associates with Mitochondria and Impairs Mitochondrial Trafficking. J. Neurosci. 2008, 28, 2783-2792. [CrossRef]

42. Mattson, M.P.; Gleichmann, M.; Cheng, A. Mitochondria in Neuroplasticity and Neurological Disorders. Neuron 2008, 60, 748-766. [CrossRef] [PubMed]

43. Greenberg, M.E.; Xu, B.; Lu, B.; Hempstead, B.L. New Insights in the Biology of BDNF Synthesis and Release: Implications in CNS Function. J. Neurosci. 2009, 29, 12764-12767. [CrossRef] [PubMed]

44. Markham, A.; Cameron, I.; Franklin, P.; Spedding, M. BDNF increases rat brain mitochondrial respiratory coupling at complex I, but not complex II. Eur. J. Neurosci. 2004, 20, 1189-1196. [CrossRef]

45. Zuccato, C.; Ciammola, A.; Rigamonti, D.; Leavitt, B.R.; Goffredo, D.; Conti, L.; MacDonald, M.E.; Friedlander, R.M.; Silani, V.; Hayden, M.; et al. Loss of Huntingtin-Mediated BDNF Gene Transcription in Huntington's Disease. Science 2001, 293, 493-498. [CrossRef]

46. Fontán-Lozano, Á.; López-Lluch, G.; Delgado-García, J.M.; Navas, P.; Carrión, Á.M. Molecular Bases of Caloric Restriction Regulation of Neuronal Synaptic Plasticity. Mol. Neurobiol. 2008, 38, 167-177. [CrossRef]

47. Browne, S.E.; Bowling, A.C.; MacGarvey, U.; Baik, M.J.; Berger, S.C.; Muquit, M.M.K.; Bird, E.D.; Beal, M.F. Oxidative damage and metabolic dysfunction in Huntington's disease: Selective vulnerability of the basal ganglia. Ann. Neurol. 1997, 41, 646-653. [CrossRef] [PubMed]

48. Benchoua, A.; Trioulier, Y.; Zala, D.; Gaillard, M.-C.; Lefort, N.; Dufour, N.; Saudou, F.; Elalouf, J.-M.; Hirsch, E.; Hantraye, P.; et al. Involvement of Mitochondrial Complex II Defects in Neuronal Death Produced by N-Terminus Fragment of Mutated Huntingtin. Mol. Biol. Cell 2006, 17, 1652-1663. [CrossRef] [PubMed]

49. Chaturvedi, R.K.; Calingasan, N.Y.; Yang, L.; Hennessey, T.; Johri, A.; Beal, M.F. Impairment of PGC-1alpha expression, neuropathology and hepatic steatosis in a transgenic mouse model of Huntington's disease following chronic energy deprivation. Hum. Mol. Genet. 2010, 19, 3190-3205. [CrossRef]

50. Chaturvedi, R.K.; Adhihetty, P.; Shukla, S.; Hennessy, T.; Calingasan, N.; Yang, L.; Starkov, A.; Kiaei, M.; Cannella, M.; Sassone, J.; et al. Impaired PGC-1 $\alpha$ function in muscle in Huntington's disease. Hum. Mol. Genet. 2009, 18, 3048-3065. [CrossRef]

51. Lin, J.; Wu, P.-H.; Tarr, P.T.; Lindenberg, K.S.; St-Pierre, J.; Zhang, C.-Y.; Mootha, V.K.; Jager, S.; Vianna, C.R.; Reznick, R.M.; et al. Defects in Adaptive Energy Metabolism with CNS-Linked Hyperactivity in PGC-1 $\alpha$ Null Mice. Cell 2004, 119, 121-135. [CrossRef]

52. Chou, S.-Y.; Lee, Y.-C.; Chen, H.-M.; Chiang, M.-C.; Lai, H.-L.; Chang, H.-H.; Wu, Y.-C.; Sun, C.-N.; Chien, C.-L.; Lin, Y.-S.; et al. CGS21680 attenuates symptoms of Huntington's disease in a transgenic mouse model. J. Neurochem. 2005, 93, 310-320. [CrossRef] [PubMed]

53. Ju, T.; Chen, H.-M.; Lin, J.-T.; Chang, C.-P.; Chang, W.-C.; Kang, J.-J.; Sun, C.-P.; Tao, M.-H.; Tu, P.-H.; Chang, C.; et al. Nuclear translocation of AMPK- $\alpha 1$ potentiates striatal neurodegeneration in Huntington's disease. J. Cell Biol. 2011, 194, 209-227. [CrossRef]

54. Glaser, T.; Andrejew, R.; Oliveira-Giacomelli, Á.; Ribeiro, D.E.; Marques, L.B.; Ye, Q.; Ren, W.-J.; Semyanov, A.; Illes, P.; Tang, Y.; et al. Purinergic Receptors in Basal Ganglia Diseases: Shared Molecular Mechanisms between Huntington's and Parkinson's Disease. Neurosci. Bull. 2020, 36, 1299-1314. [CrossRef] [PubMed]

55. Dayalu, P.; Albin, R.L. Huntington Disease: Pathogenesis and Treatment. Neurol. Clin. 2015, 33, 101-114. [CrossRef] [PubMed]

56. Patassini, S.; Begley, P.; Xu, J.; Church, S.J.; Reid, S.J.; Kim, E.H.; Curtis, M.; Dragunow, M.; Waldvogel, H.J.; Snell, R.G.; et al Metabolite mapping reveals severe widespread perturbation of multiple metabolic processes in Huntington's disease human brain. Biochim. Biophys. Acta 2016, 1862, 1650-1662. [CrossRef]

57. Nambron, R.; Silajdzic, E.; Kalliolia, E.; Ottolenghi, C.; Hindmarsh, P.; Hill, N.R.; Costelloe, S.J.; Martin, N.G.; Positano, V.; Watt, H.C.; et al. A Metabolic Study of Huntington's Disease. PLoS ONE 2016, 11, e014648. [CrossRef]

58. Gianfriddo, M.; Melani, A.; Turchi, D.; Giovannini, M.; Pedata, F. Adenosine and glutamate extracellular concentrations and mitogen-activated protein kinases in the striatum of Huntington transgenic mice. Selective antagonism of adenosine A2A receptors reduces transmitter outflow. Neurobiol. Dis. 2004, 17, 77-88. [CrossRef]

59. Lee, C.-F.; Chern, Y. Adenosine Receptors and Huntington's Disease. Int. Rev. Neurobiol. 2014, 119, 195-232. [CrossRef]

60. Glass, M.; Dragunow, M.; Faull, R. The pattern of neurodegeneration in Huntington's disease: A comparative study of cannabinoid, dopamine, adenosine and GABAA receptor alterations in the human basal ganglia in Huntington's disease. Neuroscience 2000, 97, 505-519. [CrossRef]

61. Bauer, A.; Zilles, K.; Matusch, A.; Holzmann, C.; Riess, O.; Von Hörsten, S. Regional and subtype selective changes of neurotransmitter receptor density in a rat transgenic for the Huntington's disease mutation. J. Neurochem. 2005, 94, 639-650. [CrossRef]

62. Cha, J.-H.J.; Frey, A.S.; Alsdorf, S.A.; Kerner, J.A.; Kosinski, C.M.; Mangiarini, L.; Penney, J.B.; Davies, S.W.; Bates, G.; Young, A.B. Altered neurotransmitter receptor expression in transgenic mouse models of Huntington's disease. Philos. Trans. R. Soc. B Biol. Sci. 1999, 354, 981-989. [CrossRef] 
63. Mievis, S.; Blum, D.; Ledent, C. A2A receptor knockout worsens survival and motor behaviour in a transgenic mouse model of Huntington's disease. Neurobiol. Dis. 2011, 41, 570-576. [CrossRef]

64. Villar-Menéndez, I.; Blanch, M.; Tyebji, S.; Pereira-Veiga, T.; Albasanz, J.L.; Martín, M.; Ferrer, I.; Pérez-Navarro, E.; Barrachina, M. Increased 5-Methylcytosine and Decreased 5-Hydroxymethylcytosine Levels are Associated with Reduced Striatal A2AR Levels in Huntington's Disease. NeuroMolecular Med. 2013, 15, 295-309. [CrossRef]

65. Domenici, M.; Scattoni, M.L.; Martire, A.; Lastoria, G.; Potenza, R.; Borioni, A.; Venerosi, A.; Calamandrei, G.; Popoli, P. Behavioral and electrophysiological effects of the adenosine A2A receptor antagonist SCH 58261 in R6/2 Huntington's disease mice. Neurobiol. Dis. 2007, 28, 197-205. [CrossRef]

66. Li, W.; Silva, H.; Real, J.I.; Wang, Y.-M.; Rial, D.; Li, P.; Payen, M.-P.; Zhou, Y.; Muller, C.E.; Tomé, A.R.; et al. Inactivation of adenosine A2A receptors reverses working memory deficits at early stages of Huntington's disease models. Neurobiol. Dis. 2015, 79, 70-80. [CrossRef]

67. Díaz-Hernández, M.; Díez-Zaera, M.; Sánchez-Nogueiro, J.; Gómez-Villafuertes, R.; Canals, J.M.; Alberch, J.; Miras-Portugal, M.T.; Lucas, J.J. Altered P2X7-receptor level and function in mouse models of Huntington's disease and therapeutic efficacy of antagonist administration. FASEB J. 2009, 23, 1893-1906. [CrossRef] [PubMed]

68. Busse, M.E.; Hughes, G.; Wiles, C.M.; Rosser, A.E. Use of hand-held dynamometry in the evaluation of lower limb muscle strength in people with Huntington's disease. J. Neurol. 2008, 255, 1534-1540. [CrossRef]

69. Ribchester, R.R.; Thomson, D.; Wood, N.I.; Hinks, T.; Gillingwater, T.H.; Wishart, T.M.; Court, F.A.; Morton, A.J. Progressive abnormalities in skeletal muscle and neuromuscular junctions of transgenic mice expressing the Huntington's disease mutation. Eur. J. Neurosci. 2004, 20, 3092-3114. [CrossRef] [PubMed]

70. Romer, S.H.; Metzger, S.; Peraza, K.; Wright, M.C.; Jobe, D.S.; Song, L.-S.; Rich, M.M.; Foy, B.D.; Talmadge, R.J.; Voss, A.A. A mouse model of Huntington's disease shows altered ultrastructure of transverse tubules in skeletal muscle fibers. J. Gen. Physiol. 2021, 153, 153. [CrossRef]

71. Orth, M.; Cooper, J.M.; Bates, G.; Schapira, A.H.V. Inclusion formation in Huntington's disease R6/2 mouse muscle cultures. J. Neurochem. 2003, 87, 1-6. [CrossRef] [PubMed]

72. Valadão, P.A.C.; De Aragão, B.C.; Andrade, J.N.; Magalhães-Gomes, M.P.S.; Foureaux, G.; Joviano-Santos, J.V.; Nogueira, J.C.; Machado, T.; De Jesus, I.C.G.; Nogueira, J.M.; et al. Abnormalities in the Motor Unit of a Fast-Twitch Lower Limb Skeletal Muscle in Huntington's Disease. ASN Neuro 2019, 11, 11. [CrossRef]

73. Valadão, P.A.C.; De Aragão, B.C.; Andrade, J.N.; Magalhães-Gomes, M.P.S.; Foureaux, G.; Joviano-Santos, J.V.; Nogueira, J.C.; Ribeiro, F.; Tapia, J.C.; Guatimosim, C. Muscle atrophy is associated with cervical spinal motoneuron loss in BACHD mouse model for Huntington's disease. Eur. J. Neurosci. 2016, 45, 785-796. [CrossRef]

74. Strand, A.D.; Aragaki, A.K.; Shaw, D.; Bird, T.; Holton, J.; Turner, C.; Tapscott, S.J.; Tabrizi, S.; Schapira, A.H.; Kooperberg, C.; et al. Gene expression in Huntington's disease skeletal muscle: A potential biomarker. Hum. Mol. Genet. 2005, 14, $1863-1876$. [CrossRef] [PubMed]

75. Mielcarek, M.; Toczek, M.; Smeets, C.J.L.M.; Franklin, S.A.; Bondulich, M.K.; Jolinon, N.; Muller, T.; Ahmed, M.; Dick, J.R.T.; Piotrowska, I.; et al. HDAC4-Myogenin Axis As an Important Marker of HD-Related Skeletal Muscle Atrophy. PLoS Genet. 2015, 11, e1005021. [CrossRef]

76. Ezielonka, D.; Epiotrowska, I.; Marcinkowski, J.T.; Emielcarek, M. Skeletal muscle pathology in Huntington's disease. Front. Physiol. 2014, 5, 380. [CrossRef]

77. Saft, C.; Zange, J.; Andrich, J.; Müller, K.; Lindenberg, K.; Landwehrmeyer, B.; Vorgerd, M.; Kraus, P.H.; Przuntek, H.; Schöls, L.; et al. Mitochondrial impairment in patients and asymptomatic mutation carriers of Huntington's disease. Mov. Disord. 2005, 20, 674-679. [CrossRef]

78. Kojer, K.; Hering, T.; Bazenet, C.; Weiss, A.; Herrmann, F.; Taanman, J.-W.; Orth, M. Huntingtin Aggregates and Mitochondrial Pathology in Skeletal Muscle but not Heart of Late-Stage R6/2 Mice. J. Huntington's Dis. 2019, 8, 145-159. [CrossRef]

79. Tsang, T.M.; Woodman, B.; McLoughlin, G.A.; Griffin, J.L.; Tabrizi, S.J.; Bates, G.P.; Holmes, E. Metabolic Characterization of the R6/2 Transgenic Mouse Model of Huntington's Disease by High-Resolution MAS1H NMR Spectroscopy. J. Proteome Res. 2006, 5 , 483-492. [CrossRef]

80. Ciammola, A.; Sassone, J.; Alberti, L.; Meola, G.; Mancinelli, E.; Russo, M.A.; Squitieri, F.; Silani, V. Increased apoptosis, huntingtin inclusions and altered differentiation in muscle cell cultures from Huntington's disease subjects. Cell Death Differ. 2006, 13, 2068-2078. [CrossRef] [PubMed]

81. Johri, A.; Calingasan, N.Y.; Hennessey, T.M.; Sharma, A.; Yang, L.; Wille, E.; Chandra, A.; Beal, M.F. Pharmacologic activation of mitochondrial biogenesis exerts widespread beneficial effects in a transgenic mouse model of Huntington's disease. Hum. Mol. Genet. 2011, 21, 1124-1137. [CrossRef]

82. Miller, S.G.; Hafen, P.S.; Brault, J.J. Increased Adenine Nucleotide Degradation in Skeletal Muscle Atrophy. Int. J. Mol. Sci. 2019, 21, 88. [CrossRef]

83. Lanska, D.J.; LaVine, L.; Schoenberg, B.S. Huntington's disease mortality in the United States. Neurology 1988, 38, 769. [CrossRef] [PubMed]

84. Chiu, E.; Alexander, L. Causes of death in Huntington's Disease. Med. J. Aust. 1982, 1, 153. [CrossRef] [PubMed]

85. Andrich, J.; Schmitz, T.; Saft, C.; Postert, T.; Kraus, P.; Epplen, J.T.; Przuntek, H.; Agelink, M.W. Autonomic nervous system function in Huntington's disease. J. Neurol. Neurosurg. Psychiatry 2002, 72, 726-731. [CrossRef] [PubMed] 
86. Hasselbalch, S.G.; Oberg, G.; Sorensen, S.A.; Andersen, A.R.; Waldemar, G.; Schmidt, J.F.; Fenger, K.; Paulson, O.B. Reduced regional cerebral blood flow in Huntington's disease studied by SPECT. J. Neurol. Neurosurg. Psychiatry 1992, 55, 1018-1023. [CrossRef]

87. Melik, Z.; Kobal, J.; Cankar, K.; Strucl, M. Microcirculation response to local cooling in patients with Huntington's disease. J. Neurol. 2012, 259, 921-928. [CrossRef]

88. Sharma, K.R.; Romano, J.G.; Ayyar, D.R.; Rotta, F.T.; Facca, A.; Sanchez-Ramos, J. Sympathetic Skin Response and Heart Rate Variability in Patients With Huntington Disease. Arch. Neurol. 1999, 56, 1248-1252. [CrossRef]

89. Terroba-Chambi, C.; Bruno, V.; Vigo, D.E.; Merello, M. Heart rate variability and falls in Huntington's disease. Clin. Auton. Res. 2021, 31, 281-292. [CrossRef]

90. Mielcarek, M.; Inuabasi, L.; Bondulich, M.K.; Muller, T.; Osborne, G.; Franklin, S.A.; Smith, D.L.; Neueder, A.; Rosinski, J.; Rattray, I.; et al. Dysfunction of the CNS-Heart Axis in Mouse Models of Huntington's Disease. PLoS Genet. 2014, 10, e1004550. [CrossRef] [PubMed]

91. Wood, N.I.; Sawiak, S.J.; Buonincontri, G.; Niu, Y.; Kane, A.D.; Carpenter, T.A.; Giussani, D.; Morton, A.J. Direct Evidence of Progressive Cardiac Dysfunction in a Transgenic Mouse Model of Huntington's Disease. J. Huntington's Dis. 2012, 1, 57-64. [CrossRef]

92. Kiriazis, H.; Jennings, N.L.; Davern, P.; Lambert, G.; Su, Y.; Pang, T.; Du, X.; La Greca, L.; Head, G.; Hannan, A.J.; et al. Neurocardiac dysregulation and neurogenic arrhythmias in a transgenic mouse model of Huntington's disease. J. Physiol. 2012, 590, 5845-5860. [CrossRef]

93. Mielcarek, M.; Bondulich, M.K.; Inuabasi, L.; Franklin, S.A.; Muller, T.; Bates, G.P. The Huntington's Disease-Related Cardiomyopathy Prevents a Hypertrophic Response in the R6/2 Mouse Model. PLoS ONE 2014, 9, e108961. [CrossRef] [PubMed]

94. Wu, B.-T.; Chiang, M.-C.; Tasi, C.-Y.; Kuo, C.-H.; Shyu, W.-C.; Kao, C.-L.; Huang, C.-Y.; Lee, S.-D. Cardiac Fas-Dependent and Mitochondria-Dependent Apoptotic Pathways in a Transgenic Mouse Model of Huntington's Disease. Cardiovasc. Toxicol. 2016, 16, 111-121. [CrossRef] [PubMed]

95. Joviano-Santos, J.V.; Santos-Miranda, A.; Botelho, A.F.M.; De Jesus, I.C.G.; Andrade, J.N.; Barreto, T.D.O.; Magalhães-Gomes, M.P.S.; Valadão, P.A.C.; Cruz, J.; Melo, M.M.; et al. Increased oxidative stress and CaMKIIactivity contribute to electro-mechanical defects in cardiomyocytes from a murine model of Huntington's disease. FEBS J. 2019, 286, 110-123. [CrossRef]

96. Dridi, H.; Liu, X.; Yuan, Q.; Reiken, S.; Yehia, M.; Sittenfeld, L.; Apostolou, P.; Buron, J.; Sicard, P.; Matecki, S.; et al. Role of defective calcium regulation in cardiorespiratory dysfunction in Huntington's disease. JCI Insight 2020, 5. [CrossRef]

97. Mihm, M.J.; Amann, D.M.; Schanbacher, B.L.; Altschuld, R.A.; Bauer, J.A.; Hoyt, K.R. Cardiac dysfunction in the R6/2 mouse model of Huntington's disease. Neurobiol. Dis. 2007, 25, 297-308. [CrossRef]

98. Child, D.; Lee, J.H.; Pascua, C.J.; Chen, Y.H.; Monteys, A.M.; Davidson, B.L. Cardiac mTORC1 Dysregulation Impacts Stress Adaptation and Survival in Huntington's Disease. Cell Rep. 2018, 23, 1020-1033. [CrossRef] [PubMed]

99. Critchley, B.J.; Isalan, M.; Mielcarek, M. Neuro-Cardio Mechanisms in Huntington's Disease and Other Neurodegenerative Disorders. Front. Physiol. 2018, 9, 559. [CrossRef]

100. Lodi, R.; Schapira, A.H.V.; Manners, D.; Styles, P.; Wood, N.W.; Taylor, D.J.; Warner, T.T. Abnormal in Vivo Skeletal Muscle Energy Metabolism in Huntington's Disease and Dentatorubropallidoluysian Atrophy. Ann. Neurol. 2000. [CrossRef]

101. Toczek, M.; Zielonka, D.; Zukowska, P.; Marcinkowski, J.T.; Slominska, E.; Isalan, M.; Smolenski, R.T.; Mielcarek, M. An impaired metabolism of nucleotides underpins a novel mechanism of cardiac remodeling leading to Huntington's disease related cardiomyopathy. Biochim. Biophys. Acta 2016, 1862, 2147-2157. [CrossRef] [PubMed]

102. Mielcarek, M.; Smolenski, R.; Isalan, M. Transcriptional Signature of an Altered Purine Metabolism in the Skeletal Muscle of a Huntington's Disease Mouse Model. Front. Physiol. 2017, 8. [CrossRef]

103. Toczek, M.; Kutryb-Zajac, B.; Zukowska, P.; Slominska, E.M.; Isalan, M.; Mielcarek, M.; Smolenski, R. Changes in cardiac nucleotide metabolism in Huntington's disease. Nucleosides Nucleotides Nucleic Acids 2016, 35, 707-712. [CrossRef]

104. Fortuin, F.D.; Morisaki, T.; Holmes, E.W. Subunit composition of AMPD varies in response to changes in AMPD1 and AMPD3 gene expression in skeletal muscle. Proc. Assoc. Am. Physicians 1996, 108, 329-333. [PubMed]

105. Ferrando, B.; Gomez-Cabrera, M.C.; Salvador-Pascual, A.; Puchades, C.; Derbré, F.; Gratas-Delamarche, A.; Laparre, L.; OlasoGonzález, G.; Cerda, M.; Viosca, E.; et al. Allopurinol partially prevents disuse muscle atrophy in mice and humans. Sci. Rep. 2018, 8, 1-12. [CrossRef]

106. Krasowska, E.; Róg, J.; Sinadinos, A.; Young, C.N.J.; Górecki, D.C.; Zabłocki, K. Purinergic receptors in skeletal muscles in health and in muscular dystrophy. Postępy Biochemii 2014, 60, 483-489. [PubMed]

107. Górecki, D.C. P2X7 purinoceptor as a therapeutic target in muscular dystrophies. Curr. Opin. Pharmacol. 2019, 47, 40-45. [CrossRef]

108. Ryten, M.; Yang, S.Y.; Dunn, P.M.; Goldspink, G.; Burnstock, G. Purinoceptor expression in regenerating skeletal muscle in the mdx mouse model of muscular dystrophy and in satellite cell cultures. FASEB J. 2004, 18, 1404-1406. [CrossRef] [PubMed]

109. Berry, D.A.; Barden, J.A.; Balcar, V.J.; Keogh, A.; Dos Remedios, C.G. Increase in expression of P2X1 receptors in the atria of patients suffering from dilated cardiomyopathy. Electrophoresis 1999, 20, 2059-2064. [CrossRef]

110. Yang, A.; Sonin, D.; Jones, L.; Barry, W.H.; Liang, B.T. A beneficial role of cardiac P2X4 receptors in heart failure: Rescue of the calsequestrin overexpression model of cardiomyopathy. Am. J. Physiol. Circ. Physiol. 2004, 287, H1096-H1103. [CrossRef] [PubMed] 
111. Shen, J.-B.; Cronin, C.; Sonin, D.; Joshi, B.V.; Nieto, M.G.; Harrison, D.; Jacobson, K.A.; Liang, B.T. P2X purinergic receptormediated ionic current in cardiac myocytes of calsequestrin model of cardiomyopathy: Implications for the treatment of heart failure. Am. J. Physiol. Circ. Physiol. 2007, 292, H1077-H1084. [CrossRef] [PubMed]

112. Martinez, C.G.; Zamith-Miranda, D.; Da Silva, M.G.; Ribeiro, K.C.; Brandão, I.T.; Silva, C.L.; Diaz, B.L.; Bellio, M.; Persechini, P.M.; Kurtenbach, E. P2 $\times 7$ purinergic signaling in dilated cardiomyopathy induced by auto-immunity against muscarinic M2 receptors: Autoantibody levels, heart functionality and cytokine expression. Sci. Rep. 2015, 5, 16940. [CrossRef] [PubMed]

113. Duan, W.; Jiang, M.; Jin, J. Metabolism in HD: Still a relevant mechanism? Mov. Disord. 2014, 29, 1366-1374. [CrossRef] [PubMed]

114. Dickey, A.S.; Pineda, V.V.; Tsunemi, T.; Liu, P.P.; Miranda, H.C.; Gilmore-Hall, S.K.; Lomas, N.; Sampat, K.R.; Buttgereit, A.; Torres, M.-J.M.; et al. PPAR- $\delta$ is repressed in Huntington's disease, is required for normal neuronal function and can be targeted therapeutically. Nat. Med. 2016, 22, 37-45. [CrossRef]

115. Smolenski, R.T.; Raisky, O.; Slominska, E.M.; Abunasra, H.; Kalsi, K.K.; Jayakumar, J.; Suzuki, K.; Yacoub, M.H. Protection from reperfusion injury after cardiac transplantation by inhibition of adenosine metabolism and nucleotide precursor supply. Circulation 2001, 104, 246-252. [CrossRef] [PubMed]

116. Smolenski, R.; Kalsi, K.K.; Zych, M.; Kochan, Z.; Yacoub, M.H. Adenine/Ribose Supply Increases Adenosine Production and Protects ATP Pool in Adenosine Kinase-inhibited Cardiac Cells. J. Mol. Cell. Cardiol. 1998, 30, 673-683. [CrossRef]

117. Plaideau, C.; Lai, Y.-C.; Kviklyte, S.; Zanou, N.; Löfgren, L.; Andersén, H.; Vertommen, D.; Gailly, P.; Hue, L.; Bohlooly, Y.M.; et al. Effects of Pharmacological AMP Deaminase Inhibition and Ampd1 Deletion on Nucleotide Levels and AMPK Activation in Contracting Skeletal Muscle. Chem. Biol. 2014, 21, 1497-1510. [CrossRef] [PubMed]

118. Smolenski, R.T.; Rybakowska, I.; Turyn, J.; Romaszko, P.; Zabielska, M.; Taegtmeyer, A.; Słomińska, E.M.; Kaletha, K.K.; Barton, P.J.R. AMP deaminase 1 gene polymorphism and heart disease-a genetic association that highlights new treatment. Cardiovasc. Drugs Ther. 2014, 28, 183-189. [CrossRef]

119. Zabielska, M.A.; Borkowski, T.; Slominska, E.M.; Smolenski, R.T. Inhibition of AMP deaminase as therapeutic target in cardiovascular pathology. Pharmacol. Rep. 2015, 67, 682-688. [CrossRef]

120. Guieu, R.; Deharo, J.-C.; Maille, B.; Crotti, L.; Torresani, E.; Brignole, M.; Parati, G. Adenosine and the Cardiovascular System: The Good and the Bad. J. Clin. Med. 2020, 9, 1366. [CrossRef]

121. Boison, D. Role of adenosine in status epilepticus: A potential new target? Epilepsia 2013, 54 (Suppl. 6) (Suppl. 6), 20-22. [CrossRef]

122. Boison, D. Adenosine dysfunction in epilepsy. Glia 2012, 60, 1234-1243. [CrossRef]

123. Kutryb-Zajac, B.; Mierzejewska, P.; Slominska, E.M.; Smolenski, R.T. Therapeutic Perspectives of Adenosine Deaminase Inhibition in Cardiovascular Diseases. Molecules 2020, 25, 4652. [CrossRef] [PubMed]

124. Kao, Y.-H.; Lin, M.-S.; Chen, C.-M.; Wu, Y.-R.; Chen, H.-M.; Lai, H.-L.; Chern, Y.; Lin, C.-J. Targeting ENT1 and adenosine tone for the treatment of Huntington's disease. Hum. Mol. Genet. 2016, 26, 467-478. [CrossRef]

125. Mezzaroma, E.; Toldo, S.; Farkas, D.; Seropian, I.M.; Van Tassell, B.W.; Salloum, F.; Kannan, H.R.; Menna, A.C.; Voelkel, N.F.; Abbate, A. The inflammasome promotes adverse cardiac remodeling following acute myocardial infarction in the mouse. Proc. Natl. Acad. Sci. USA 2011, 108, 19725-19730. [CrossRef] [PubMed]

126. Gao, H.; Yin, J.; Shi, Y.; Hu, H.; Li, X.; Xue, M.; Cheng, W.; Wang, Y.; Li, X.; Li, Y.; et al. Targeted P2X7R shRNA delivery attenuates sympathetic nerve sprouting and ameliorates cardiac dysfunction in rats with myocardial infarction. Cardiovasc. Ther. 2016, 35, e12245. [CrossRef] [PubMed]

127. Bracey, N.A.; Beck, P.L.; Muruve, D.A.; Hirota, S.A.; Guo, J.; Jabagi, H.; Jr, J.R.W.; Macdonald, J.A.; Lees-Miller, J.P.; Roach, D.; et al. The Nlrp3 inflammasome promotes myocardial dysfunction in structural cardiomyopathy through interleukin-1 $\beta$. Exp. Physiol. 2013, 98, 462-472. [CrossRef]

128. Frantz, S.; Ducharme, A.; Sawyer, D.; Rohde, L.E.; Kobzik, L.; Fukazawa, R.; Tracey, D.; Allen, H.; Lee, R.T.; Kelly, R.A. Targeted deletion of caspase-1 reduces early mortality and left ventricular dilatation following myocardial infarction. J. Mol. Cell. Cardiol. 2003, 35, 685-694. [CrossRef] 